\title{
Analisa Korelasi Nilai Konduktivitas Air Pendingin Terhadap Efisiensi Turbin Uap PLTP Karaha
}

\author{
Ernanda Ginting ${ }^{1)^{*}}$, Aryantono Mortowidjojo ${ }^{2)}$, Priyono Atmadi ${ }^{3)}$ \\ 1,2,3) Jurusan Teknik Mesin, Fakultas Teknik Mesin, Universitas Kristen Indonesia \\ JI. Mayjen Sutoyo No.2, RT.9/RW.6, Cawang, Kec. Kramat jati, Kota Jakarta Timur, DKI Jakarta 13650 \\ Email: ernanda.ginting@rocketmail.com; aryantono@uki.ac.id; priyono.atmadi@uki.ac.id
}

doi: https://doi.org/10.24843/METTEK.2021.v07.i01.p03

\begin{abstract}
Abstrak
Uap yang digunakan sebagai penggerak turbin berasal dari sumur produksi dua fasa dengan karakteristik water dominated. Selain water dominated, uap dari sumur mengandung banyak mineral dari perut bumi seperti Silika, Klorida, Sodium, Kalsium, Sulfate, Potasium, Magnesium, Boron dan Iron. Mineral tersebut ikut terlarut bersama uap yang terkondensasi menjadi kondensat, kondensat yang didinginkan untuk dipakai kembali sebagai air pendingin mengandung zat-zat pengotor yang mempengaruhi proses heat mass balance PLTP Karaha 1x30MW.Kondisi tersebut merupakan masalah yang diangkat pada penelitian ini dengan melakukan uji analisa korelasi konduktivitas air pendingin terhadap efisiensi PLTP Karaha 1x30MW dengan menggunakan software orange 3.27.1.Dari hasil analisa pearson correlation, scatter plot dan distributions didapatkan korelasi yang cukup kuat antara konduktivitas air terhadap efisiensi turbin dengan nilai koefisien pearson correlation yang sebesar -0.436. Konduktivitas air pendingin dengan nilai rata-rata $1181 \mu \mathrm{S} / \mathrm{cm}$ memiliki efisiensi turbin diatas $71.5 \%$, sedangkan konduktivitas air pendingin dengan nilai rata-rata $1248 \mu \mathrm{S} / \mathrm{cm}$ memiliki efisiensi turbin dibawah $66.4 \%$. Sehingga dapat disimpulkan kenaikan dan penurunan konduktivitas air pendingin memiliki korelasi dengan efisiensi turbin uap PLTP Karaha 1x30 MW.
\end{abstract}

Kata kunci: Konduktivitas air, turbin uap, efisiensi, analisa korelasi, panas bumi

\begin{abstract}
The steam used to drive the turbine comes from a two-phase production well with the characteristic of being water dominated. Apart from water dominated, steam from the wells contains many minerals from the bowels of the earth, such as Silica, Chloride, Sodium, Calcium, Sulfate, Potassium, Magnesium, Boron and Iron. These minerals are also dissolved with the steam which condenses into condensate, condensate which is cooled to be reused as cooling water contains impurities that affect the heat mass balance process of PLTP Karaha 1x30MW.This condition is a problem that is raised in this research by analyzing the correlation analysis of cooling water conductivity to the efficiency of Karaha 1x30MW PLTP using orange 3.27.1 software.From the analysis of the pearson correlation, scatter plot and distributions, it was found that there was a strong correlation between water conductivity and turbine efficiency with the pearson correlation coefficient value of -0.436. The conductivity of the cooling water with an average value of $1181 \mu \mathrm{S} / \mathrm{cm}$ has a turbine efficiency above $71.5 \%$, while the conductivity of the cooling water with an average value of $1248 \mu \mathrm{S} / \mathrm{cm}$ has a turbine efficiency below 66.4\%. So it can be concluded that the increase and decrease in cooling water conductivity has a correlation with the efficiency of the Karaha 1x30 MW PLTP steam turbine.
\end{abstract}

Keywords: Water conductivity, steam turbine, efficiency, correlation analysis, geothermal

Penulis korespondensi,

Email: ernanda.ginting@ rocketmail.com 


\section{PENDAHULUAN}

Fluida yang mengalir dari perut bumi mengandung mineral yang tersimpan dari batuan reservoir panas bumi. Menurut Saptadji fluida panas bumi terdiri dari kandungan Klorida, Natrium, Kalium, Silika dan mineral lainnya. Kandungan mineral dapat berbeda-beda tergantung karakter batuan, temperatur reservoir serta lokasi sumur panas bumi tersebut [1]. Uap yang mengandung mineral tersebut masuk turbin sebagai media penggerak dan keluar di last stage turbin. Selanjutnya uap dikondensasikan di kondensor dengan air pendingin dari menara pendingin. Hasil kondensasi tersebut menghasilkan Non Condensable Gas (NCG) yang diekstraksikan, selanjutnya air kondensat didinginkan untuk dimanfaatkan kembali sebagai air pendingin. Namun air pendingin yang berasal dari kondensat ini memiliki kandungan mineral yang terus terakumulasi dan mengendap, semakin banyak dan lama kandungan mineral yang terakumulasi dapat menimbulkan deposit bahkan lebih ekstrem dapat menimbulkan lumut. Kondensat yang disirkulasikan menjadi air pendingin harus dijaga kualitasnya, seperti temperatur, laju aliran, nilai $\mathrm{pH}$ dan konduktivitas. Lestari et al menyebutkan bahwa konduktivitas didefinisikan sebagai ukuran suatu larutan dalam kemampuannya menghantarkan arus listrik, sehingga kadar ion maupun zat yang terlarut dalam air pendingin dapat diperkirakan dari nilai konduktivitas nya [2]. Semakin besar nilai konduktivitas menggambarkan semakin banyak unsur pengotor (impurities) yang terkandung dalam air pendingin. Unsur-unsur impurities ini terdiri dari garam, kalsium, mangan, silika dan lumpur yang dapat mengurangi kemampuan perpindahan panas [3]. Fluida pendingin yang memiliki nilai konduktivitas tinggi berarti memiliki perpindahan panas yang buruk. Djunaidi et al dalam penelitiannya menyebutkan temperatur air pendingin mempengaruhi proses kondensasi yang terjadi di kondensor, semakin rendah temperatur air pendingin maka semakin cepat terjadinya proses kondensasi sehingga kevakuman meningkat [4]. Tingkat kevakuman kondensor dipengaruhi oleh debit air dan temperatur air pendingin yang masuk, semakin vakum kondensor maka dapat memaksimalkan energi panas yang dimanfaatkan untuk memproduksi listrik. Produksi daya listrik yang sama dengan kevakuman yang berbeda dapat berpengaruh dengan laju massa uap atau yang biasa disebut specific steam consumption. Semakin sedikit uap yang dibutuhkan maka tingkat efisiensi semakin tinggi.

Komposisi mineral setiap PLTP berbeda-beda sehingga diperlukan analisa korelasi nilai konduktivitas air pendingin terhadap efisiensi turbin uap PLTP Karaha untuk mendapatkan efisiensi turbin. Analisa korelasi melibatkan laju aliran uap, temperatur air pendingin, tekanan kondensor dan konduktivitas air pendingin dilakukan menggunakan software Orange 3.27.1.

\section{METODE}

Analisa pengaruh nilai konduktivitas air pendingin terhadap efisiensi turbin diawali dengan pengumpulan data lapangan dan melakukan perhitungan efisiensi turbin. Kalkulasi dilakukan terhadap parameter-parameter lapangan yang telah dikumpulkan dari PLTP Karaha selama bulan Agustus hingga bulan November 2020, data lapangan yang dikumpulkan terdiri dari laju aliran massa uap, tekanan inlet turbin, temperatur inlet, tekanan exhaust turbin, temperatur exhaust turbin. Hasil kalkulasi efisiensi turbin diuji korelasi dengan parameter yang memiliki pengaruh terhadap efisiensi turbin seperti konduktivitas air pendingin, temperatur air pendingin dan tekanan kondensor. Uji statistik yang dilakukan adalah dengan analisa korelasi menggunakan software Orange 3.27.1.

\subsection{Perhitungan Efisiensi Turbin}

Efisiensi dapat diketahui dengan membandingkan kerja ideal turbin dengan kerja aktual turbin. Persamaan efisiensi turbin uap dapat dilihat melalui persamaan berikut [5]:

$$
\eta_{\text {isentropik }}=\frac{\text { Wturbin aktwal }}{W_{\text {turbin ideal }}} \times 100 \%
$$


Selanjutnya untuk mendapatkan besar kerja turbin ideal, dapat dihitung dengan cara menghitung entalpi uap masuk turbin $\left(h_{1}\right)$ dengan entalpi uap isentropik keluar turbin $\left(h_{2}\right)$

$$
\mathrm{Wt}=\operatorname{m} \times\left(h_{1}-h_{2}\right)
$$

Nilai entalpi uap masuk ke turbin $\left(h_{1}\right)$ dapat dicari pada property steam table. Nilai $\left(h_{1}\right)$ didapat dengan mengacu nilai temperatur uap masuk kedalam turbin. Sedangkan entalpi uap isentropik keluar turbin $\left(h_{2}\right)$ dapat dihitung bila nilai fraksi uap $(x)$ telah diketahui.

$$
\begin{aligned}
& h_{2}=h_{f}+x \cdot h_{f g} \\
& x=\frac{s_{\mathrm{z}}-s_{f}}{s_{f g}} \times 100 \%
\end{aligned}
$$

Untuk mendapatkan nilai entropi uap keluar turbin $\left(S_{2}\right)$, entropi saturasi fasa fluid $\left(S_{f}\right)$, entropi saturasi fasa campuran $\left(S f_{g}\right)$ dapat dicari dari steam table dengan mengacu pada tekanan inlet turbin dan temperature exhaust turbin.

\subsection{Korelasi Konduktivitas Air \& Efisiensi}

Konduktivitas air merupakan gambaran kadar ion yang terlarut di dalam larutan. Kadar ion dan unsur pengotor yang tinggi di dalam air akan mengurangi tingkat kemurnian air tersebut. Kondensat dari uap panas bumi mengandung banyak mineral seperti garam, Silika, natrium dan mineral lainnya. Menurut Lestari et al, Silika yang terkandung dalam air pendingin akan mengendap dan mengakibatkan turunnya efisiensi perpindahan panas [2]. Sehingga sebagai air pendingin yang memiliki peran heat transfer dalam proses kondensasi di dalam kondensor, memiliki nilai konduktivitas yang tinggi dapat menurunkan performa perpindahan panasnya. Tekanan kondensor yang semakin vakum dapat membantu kerja turbin dalam memaksimalkan energi panas uap yang masuk sehingga konsumsi uap semakin sedikit dalam membangkitkan listrik per kWh-nya. Uap panas bumi yang dikonsumsi semakin sedikit dalam pembangkitan yang sama merupakan gambaran tingkat efisiensi yang baik. Korelasi seluruh parameter yang terlibat terhadap efisiensi turbin tersebut perlu dianalisa sehingga dapat diketahui korelasi terkuat antar parameter.

\subsection{Pemodelan \& Simulasi Korelasi Efisiensi Turbin}

Analisa korelasi efisiensi turbin uap PLTP Karaha dengan parameter yang memiliki efektifitas terhadap kerja turbin diuji dengan menggunakan uji analisa pearson correlation, scatter plot dan distributions. Dengan menggunakan metode analisa pearson correlation membantu untuk mendeskripsikan hubungan antar variabel uji sehingga dapat diketahui arah dan kekuatan ketergantungan satu dengan yang lainnya [6]. Scatter plot membantu menggambarkan sebaran serta visualisasi arah korelasi antar variabel x dan $\mathrm{y}$. 


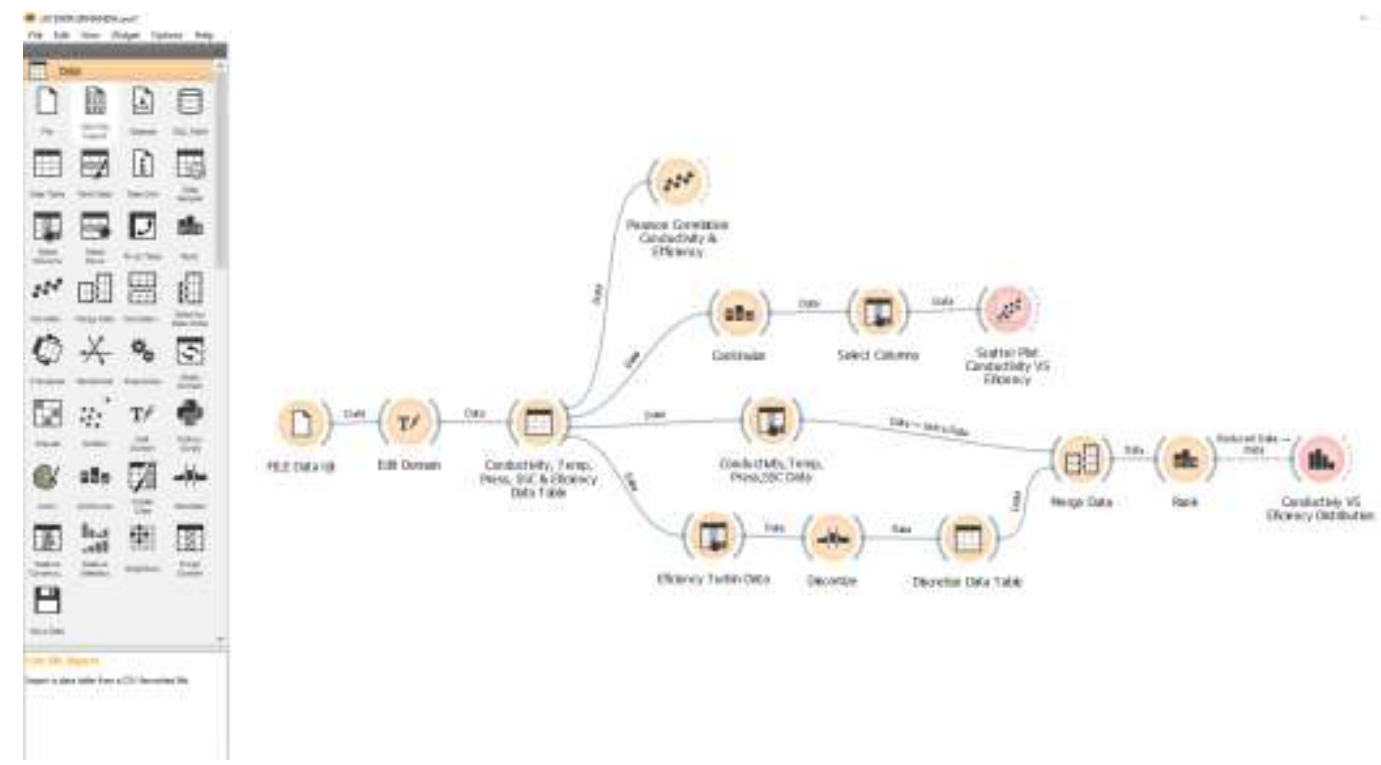

Gambar 1. Pemodelan analisa korelasi

Pemodelan analisa korelasi divisualisasikan pada Gambar 1. Software memberikan nilai koefisien pearson correlation, diagram scatter plot dan grafik distribusi dari efisiensi turbin terhadap setiap parameter uji.

\section{HASIL DAN PEMBAHASAN}

\subsection{Hasil Perhitungan Efisiensi Turbin}

Dari data lapangan yang dikumpulkan dan dilakukan perhitungan didapatkan nilai efisiensi turbin uap PLTP Karaha adalah sebagai berikut. Data tersebut selanjutnya diuji menggunakan software Orange 3.27.1.

\begin{tabular}{|c|c|c|c|c|}
\hline No. & Date Time & $\begin{array}{l}\text { Daya } \\
\text { Ideal } \\
\text { (MW) }\end{array}$ & $\begin{array}{l}\text { Daya } \\
\text { Aktual } \\
\text { (MN) }\end{array}$ & $\begin{array}{c}\text { Efficiency } \\
\text { turbin } \\
(\%)\end{array}$ \\
\hline 1 & 30 -Nov 20 & 15.752 & 9.845 & 62.500 \\
\hline 2 & 29-Nov-20 & 16.002 & 10,083 & 63.010 \\
\hline 3 & 28-Nov-20 & 15.852 & 9.942 & 62.719 \\
\hline 4 & 27-Nov 20 & 15.945 & 10.039 & 62.959 \\
\hline 5 & 26-Nov-20 & 16.008 & 10.155 & 63.439 \\
\hline 6 & 25-Nov-20 & 15.770 & 9.851 & 62,466 \\
\hline 7 & 24-Nov-20 & 15.830 & 9.901 & 62.545 \\
\hline 8 & 23-Nov-20 & 18.834 & 13.083 & 69.466 \\
\hline 9 & 22-Nov-20 & 20.054 & 14,341 & 71.511 \\
\hline 10 & 21-Nov-20 & 20.981 & 15.303 & 72.938 \\
\hline 11 & 20 -Nov-20 & 21.115 & 15.439 & 73.118 \\
\hline 12 & 19-Nov-20 & 21.385 & 15.718 & 73.499 \\
\hline 13 & 18-Nov-20 & 21.409 & 15.748 & 73.558 \\
\hline 14 & 17-Nov-20 & 21.396 & 16.313 & 76.244 \\
\hline 15 & 16-Nov-20 & 22.206 & 16.580 & 74.665 \\
\hline 16 & 15-Nov- 20 & 22.585 & 17.030 & 75.405 \\
\hline 17 & \begin{tabular}{|l|}
$14-$ Ilov 20 \\
\end{tabular} & 23.160 & 17,600 & 75.993 \\
\hline 18 & 13-Nov-20 & 20.763 & 15.050 & 72.486 \\
\hline 19 & 12 -Nlov 20 & 17.421 & 11.541 & 66.249 \\
\hline 20 & 11-Nov-20 & 16.219 & 10.296 & 63.482 \\
\hline 21 & 10 -Nlov-20 & 16.284 & 10.369 & 63.676 \\
\hline 22 & 09-Nov-20 & 16.327 & 10.445 & 63.972 \\
\hline 23 & 08-Nov-20 & 16.478 & 10.636 & 64.548 \\
\hline 24 & 07-Nov-20 & 16.294 & 10.371 & 63.648 \\
\hline 25 & $06-$ Nov-20 & 16.477 & 10.594 & 64.297 \\
\hline 26 & 05-Nov- 20 & 16.407 & 10.526 & 64.157 \\
\hline 27 & 04-Nov- 20 & 16.855 & 11.266 & 66.840 \\
\hline 28 & 03-Nov - 20 & 16.301 & 10.791 & 66.199 \\
\hline 29 & $02-$ Nov - 20 & 16.490 & 10.942 & 66.357 \\
\hline 30 & 01-Nov - 20 & 16.613 & 11.055 & 66.542 \\
\hline
\end{tabular}

\begin{tabular}{|l|l|l|l|l|}
\hline No. & Date Time & $\begin{array}{c}\text { Daya } \\
\text { Ideal } \\
\text { (MW) }\end{array}$ & $\begin{array}{c}\text { Daya } \\
\text { Actual } \\
\text { (MW) }\end{array}$ & $\begin{array}{c}\text { Efficiency } \\
\text { turbin } \\
\text { (\%) }\end{array}$ \\
\hline 31 & 31 -Oct-20 & 16.925 & 11.347 & 67.043 \\
\hline 32 & $30-$ Oct-20 & 17.165 & 11.544 & 67.255 \\
\hline 33 & $29-$ Oct-20 & 18.889 & 13.124 & 69.481 \\
\hline 34 & $28-$ Oct-20 & 18.456 & 12.706 & 68.845 \\
\hline 35 & $27-$ Oct-20 & 18.063 & 12.322 & 68.215 \\
\hline 36 & $26-$ Oct-20 & 18.463 & 12.693 & 68.749 \\
\hline 37 & 25-Oct-20 & 18.236 & 12.494 & 68.513 \\
\hline 38 & $24-$ Oct-20 & 18.169 & 12.440 & 68.467 \\
\hline 39 & $23-$ Oct-20 & 17.891 & 12.177 & 68.063 \\
\hline 40 & $22-$ Oct-20 & 19.012 & 13.188 & 69.366 \\
\hline 41 & $21-$ Oct-20 & 19.651 & 13.790 & 70.176 \\
\hline 42 & $20-$ Oct-20 & 20.193 & 14.364 & 71.133 \\
\hline 43 & $19-$ Oct-20 & 20.563 & 14.697 & 71.472 \\
\hline 44 & $18-$ Oct-20 & 20.677 & 14.812 & 71.634 \\
\hline 45 & $17-$ Oct-20 & 21.226 & 15.304 & 72.102 \\
\hline 46 & $16-$ Oct-20 & 21.194 & 15.263 & 72.015 \\
\hline 47 & $15-$ Oct-20 & 22.367 & 16.354 & 73.116 \\
\hline 48 & $14-$ Oct-20 & 22.699 & 16.655 & 73.372 \\
\hline 49 & $13-$ Oct-20 & 19.238 & 13.467 & 70.003 \\
\hline 50 & $12-$ Oct-20 & 19.657 & 13.865 & 70.536 \\
\hline 51 & $11-$ Oct-20 & 19.999 & 14.195 & 70.979 \\
\hline 52 & $10-$ Oct-20 & 20.924 & 15.044 & 71.899 \\
\hline 53 & $09-$ Oct-20 & 16.813 & 11.331 & 67.393 \\
\hline 54 & $08-$ Oct-20 & 16.993 & 11.453 & 67.396 \\
\hline 55 & $07-$ Oct-20 & 16.321 & 10.441 & 63.973 \\
\hline 56 & $06-$ Oct-20 & 17.850 & 10.410 & 58.319 \\
\hline 57 & $05-$ Oct-20 & 16.424 & 10.465 & 63.719 \\
\hline 58 & $04-$ Oct-20 & 15.684 & 10.432 & 66.512 \\
\hline 59 & $03-$ Oct-20 & 16.110 & 10.635 & 66.014 \\
\hline 60 & $02-$ Oct-20 & 19.099 & 13.337 & 69.829 \\
\hline & & & & \\
\hline
\end{tabular}

\begin{tabular}{|l|l|c|c|c|}
\hline No. & Date Time & $\begin{array}{c}\text { Daya } \\
\text { Ideal } \\
\text { (MW) }\end{array}$ & $\begin{array}{c}\text { Daya } \\
\text { Aktual } \\
\text { (MW) }\end{array}$ & $\begin{array}{c}\text { Efficiency } \\
\text { turbin } \\
\text { (\%) }\end{array}$ \\
\hline 61 & 01-Oct-20 & 17.211 & 13.383 & 77.758 \\
\hline 62 & 30-Sep-20 & 17.183 & 13.276 & 77.261 \\
\hline 63 & 29-Sep-20 & 21.531 & 13.384 & 62.161 \\
\hline 64 & 28-Sep-20 & 19.804 & 13.376 & 67.543 \\
\hline 65 & 27-Sep-20 & 20.733 & 13.643 & 65.803 \\
\hline 66 & 26-Sep-20 & 19.647 & 13.868 & 70.587 \\
\hline 67 & 25-Sep-20 & 20.921 & 14.225 & 67.994 \\
\hline 68 & 24-Sep-20 & 15.599 & 10.774 & 69.070 \\
\hline 69 & 23-Sep-20 & 15.863 & 11.159 & 70.346 \\
\hline 70 & 22-Sep-20 & 15.726 & 11.055 & 70.297 \\
\hline 71 & 21-Sep-20 & 15.125 & 10.808 & 71.459 \\
\hline 72 & 20-Sep-20 & 15.125 & 10.808 & 71.459 \\
\hline 73 & 19-Sep-20 & 15.125 & 10.808 & 71.459 \\
\hline 74 & 18-Sep-20 & 15.125 & 10.808 & 71.459 \\
\hline 75 & 17-Sep-20 & 15.125 & 10.808 & 71.459 \\
\hline 76 & 16-Sep-20 & 15.100 & 10.714 & 70.953 \\
\hline 77 & 15-Sep-20 & 19.563 & 12.588 & 64.347 \\
\hline 78 & 14-Sep-20 & 20.118 & 14.324 & 71.200 \\
\hline 79 & 13-Sep-20 & 19.643 & 14.540 & 74.021 \\
\hline 80 & 12-Sep-20 & 21.270 & 14.805 & 69.606 \\
\hline 81 & 11-Sep-20 & 20.946 & 15.106 & 72.118 \\
\hline 82 & 10-Sep-20 & 21.122 & 15.523 & 73.491 \\
\hline 83 & 09-Sep-20 & 19.486 & 13.484 & 69.199 \\
\hline 84 & 08-Sep-20 & 17.340 & 12.405 & 71.538 \\
\hline 85 & 07-Sep-20 & 17.904 & 11.985 & 66.939 \\
\hline 86 & 06-Sep-20 & 19.334 & 13.481 & 69.726 \\
\hline 87 & 05-Sep-20 & 18.221 & 13.565 & 74.447 \\
\hline 88 & 04-Sep-20 & 19.541 & 13.487 & 69.018 \\
\hline 89 & 03-Sep-20 & 19.117 & 13.788 & 72.124 \\
\hline 90 & 02-Sep-20 & 19.186 & 13.531 & 70.526 \\
\hline & & & & \\
\hline
\end{tabular}

\begin{tabular}{|c|c|c|c|c|}
\hline vo. & Date Time & Ideal & \begin{tabular}{|c|} 
Daya \\
Alkual \\
(MW)
\end{tabular} & tur \\
\hline 1 & & & & \\
\hline 2 & & & & \\
\hline 93 & $30-A$ & 86 & & \\
\hline 94 & $29 \mathrm{~A}$ & & & \\
\hline 95 & $28 \mathrm{~A}$ & & & \\
\hline 6 & $27-A$ & & & \\
\hline & $2 G A$ & & & \\
\hline & $25 \mathrm{~A}$ & & & \\
\hline 50 & $24 A$ & & & \\
\hline 00 & $23 A$ & & & \\
\hline & $22 A$ & & & \\
\hline & 21-A & & & \\
\hline & $20-A u g-20$ & & & \\
\hline & 20 & & & \\
\hline & & & & \\
\hline & & & & \\
\hline & $1 G A$ & & & \\
\hline & 20 & & & \\
\hline & 20 & & & \\
\hline & 20 & & & \\
\hline & 12 - Aug - 20 & & & \\
\hline & & & & \\
\hline & 10 - Aug- 20 & & & \\
\hline & 09 Aug - 20 & & & \\
\hline & 08 Aug 20 & & & \\
\hline & 07 -Aug 20 & & & \\
\hline & $0 G \mathrm{~A}$ & & & \\
\hline & 20 & & & \\
\hline & & & & \\
\hline & & & & \\
\hline & & & & \\
\hline & & & & \\
\hline
\end{tabular}

Gambar 1. Hasil perhitungan efisiensi turbin uap PLTP Karaha 


\subsection{Analisa Korelasi Konduktivitas Air Pendingin}

Uji korelasi yang digunakan adalah pearson correlation yang hasilnya dapat dilihat pada Gambar 2. berikut.

\begin{tabular}{|c|c|c|c|c|}
\hline \multicolumn{2}{|c|}{$*$ Correlations } & - & $\square$ & $\times$ \\
\hline \multicolumn{3}{|c|}{ Pearson correlation } & & $v$ \\
\hline \multicolumn{3}{|c|}{ W CONDUCTIVITY AIR PENDINGIN $\left.\alpha_{1}\right)$} & & $\checkmark$ \\
\hline \multicolumn{5}{|l|}{ Filter ... } \\
\hline $1+0.666$ & CONDUCTIVITY AIR PENDINGIN (X1) & PRESS CONDENSOR (X3) & & \\
\hline $2+0.520$ & CONDUCTVITY AIR PENDINGIN (X1) & TEMP AIR PENDINGIN (X2) & & \\
\hline $3-0.436$ & CONDUCTIVITY AIR PENDINGIN (X1) & EFFICIENCY TURBIN (M) & & \\
\hline $4+0.302$ & CONDUCTIVITY AIR PENDINGIN (X1) & STEAM FLOW $(X 4)$ & & \\
\hline \multicolumn{5}{|c|}{ Finished } \\
\hline \multicolumn{5}{|c|}{ P [圆|ت122 E 122} \\
\hline
\end{tabular}

Gambar 3. Pearson correlation konduktivitas air

Hasil dari uji pearson correlation terhadap konduktivitas air yang ditunjukkan pada Gambar 3, dapat menggambarkan kekuatan korelasi konduktivitas air pendingin dengan tekanan kondensor, temperatur air pendingin, laju aliran uap dan efisiensi turbin. Nilai koefisien korelasi konduktivitas dengan tekanan kondensor sebesar $r=+0.666$, nilai tersebut dapat di interpretasikan bahwa korelasi konduktivitas air pendingin terhadap tekanan kondensor memiliki hubungan yang kuat dan searah. Peningkatan nilai konduktivitas air berkorelasi dengan tekanan kondensor yang semakin meningkat atau kevakuman kondensor memburuk. Jika konduktivitas bertambah, maka tekanan di dalam kondensor juga bertambah sehingga berdampak kepada penurunan nilai efisiensi turbin uap. Hasil ini dibuktikan dari data sampel dengan nilai konduktivitas tertinggi sebesar $1479 \mu \mathrm{S} / \mathrm{cm}$ dan nilai tekanan kondensor paling buruk sebesar 0.07 barA. Visualisasi korelasi keduanya dapat digambarkan pada gambar scatter plot berikut.

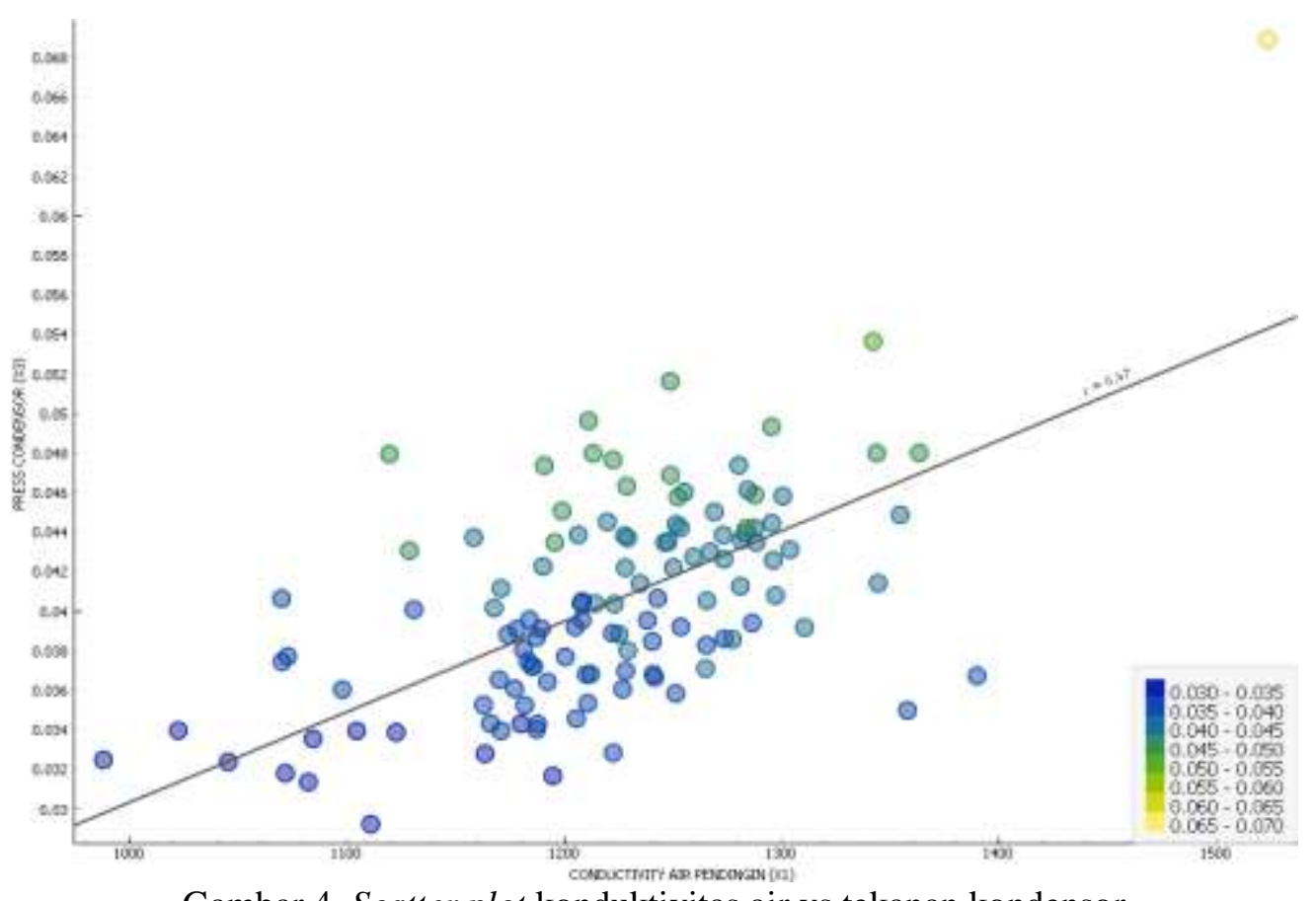

Gambar 4. Scatter plot konduktivitas air vs tekanan kondensor 
Nilai koefisien korelasi konduktivitas dan laju aliran uap sebesar $r=+0.52$, nilai tersebut dapat di interpretasikan bahwa korelasi konduktivitas air pendingin terhadap temperatur air pendingin memiliki hubungan yang cukup kuat dan searah. Penurunan nilai konduktivitas air berkorelasi dengan temperatur air pendingin yang semakin dingin. Hasil ini dibuktikan dari data sampel dengan nilai konduktivitas terendah sebesar $994.59 \mu \mathrm{S} / \mathrm{cm}$ dan nilai temperatur air pendingin yang rendah sebesar $18.9{ }^{\circ} \mathrm{C}$. Visualisasi korelasi keduanya dapat digambarkan pada gambar scatter plot berikut.

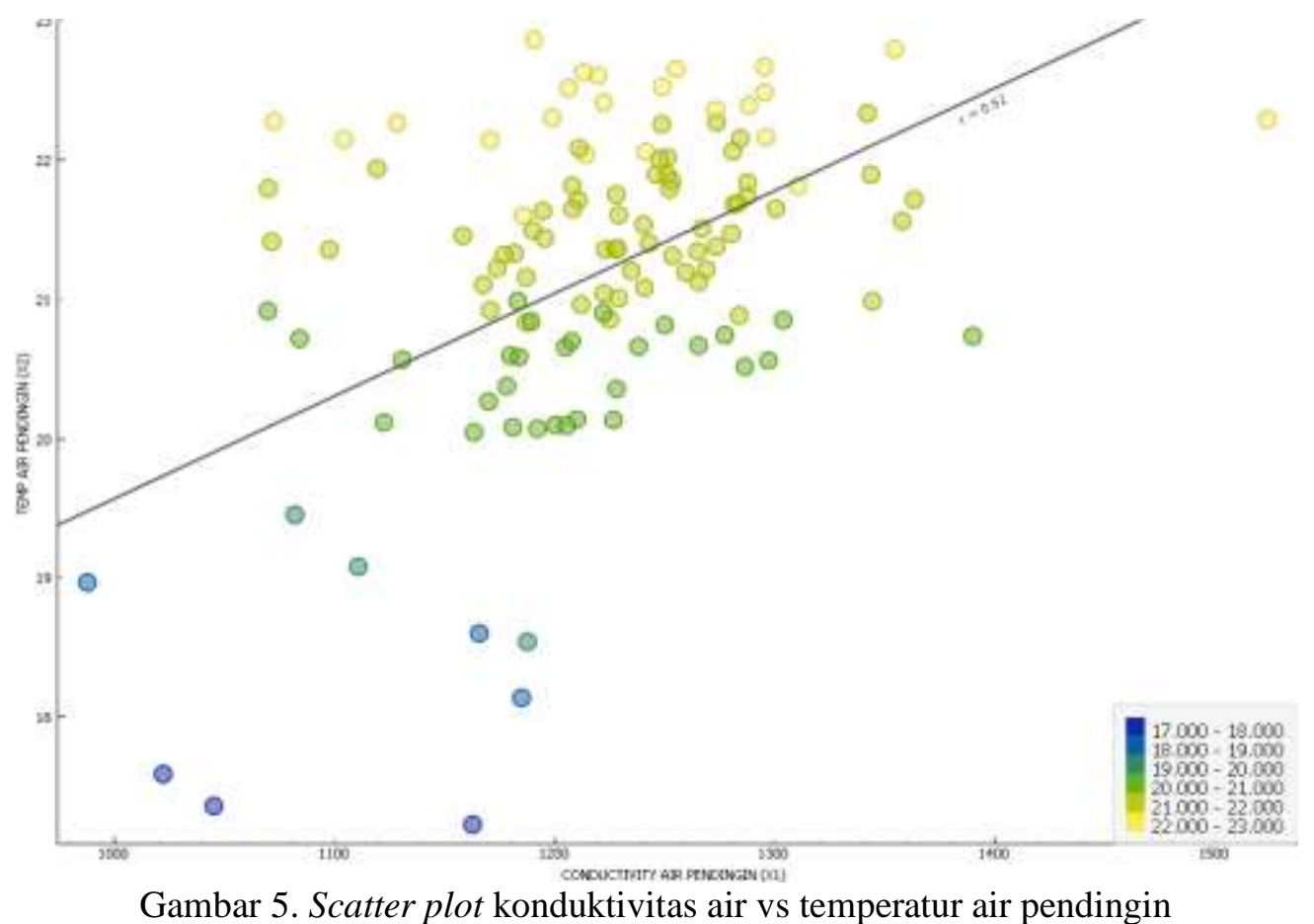

Nilai koefisien korelasi konduktivitas dan laju aliran uap sebesar $\mathrm{r}=+0.302$, nilai tersebut dapat diinterpretasikan bahwa korelasi konduktivitas air pendingin terhadap laju aliran uap memiliki hubungan yang lemah dan searah. Peningkatan nilai konduktivitas air berkorelasi dengan laju aliran uap yang semakin meningkat walaupun tidak signifikan. Visualisasi korelasi ini dapat dibuktikan pada gambar scatter plot berikut. 


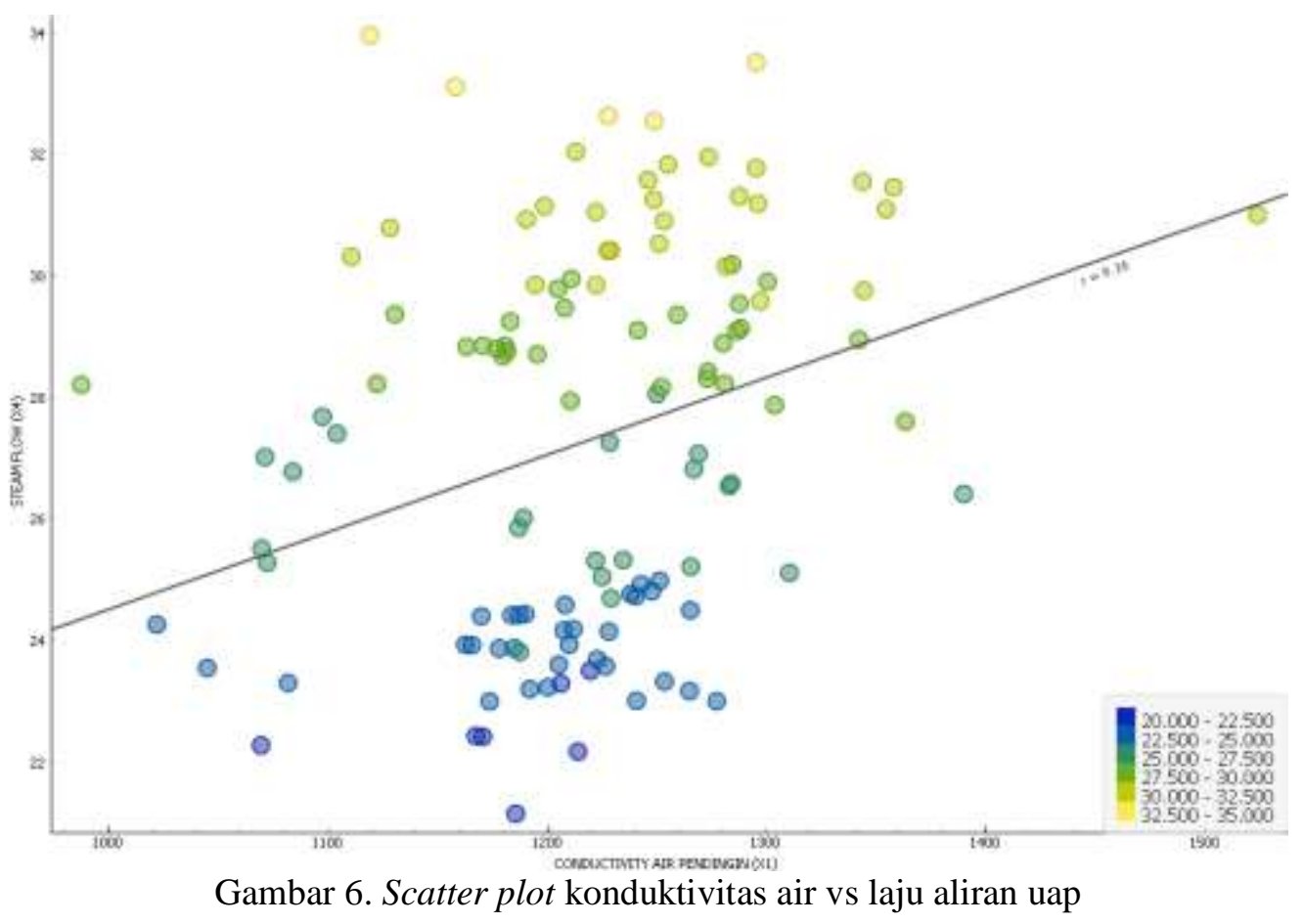

\subsection{Analisa Korelasi Efisiensi Turbin}

Uji korelasi yang digunakan adalah pearson correlation yang hasilnya dapat dilihat pada gambar berikut.

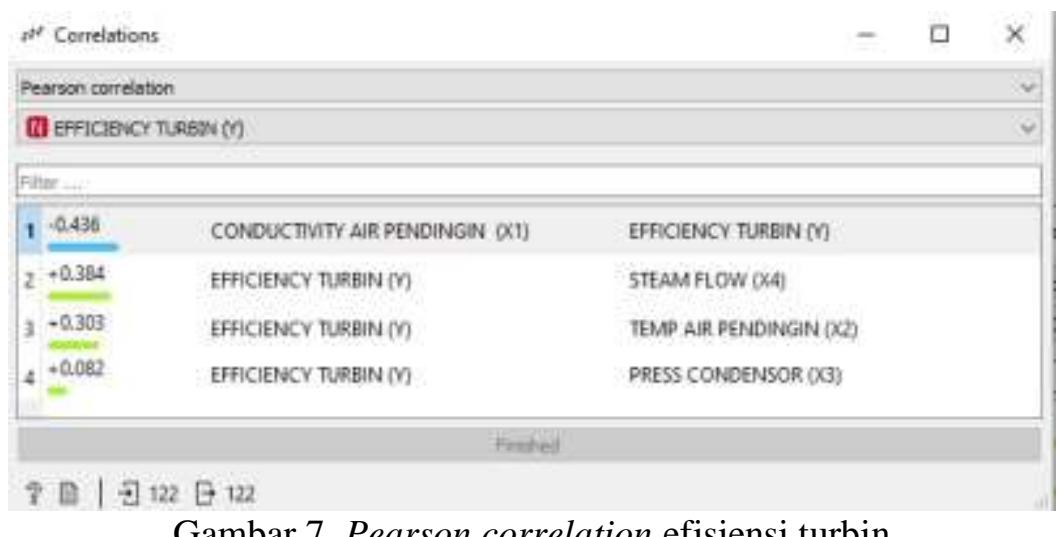

Hasil dari uji pearson correlation terhadap efisiensi turbin uap yang ditunjukkan pada Gambar 7., dapat menggambarkan kekuatan korelasi efisiensi turbin uap dengan konduktivitas air, tekanan kondensor, temperatur air pendingin dan laju aliran uap. Korelasi efisiensi terhadap konduktivitas air pendingin memiliki nilai koefisien korelasi terbesar diantara parameter lainnya dengan nilai $r=-0.436$, nilai tersebut dapat diinterpretasikan bahwa korelasi konduktivitas air pendingin terhadap efisiensi turbin memiliki hubungan yang cukup kuat dan berlawan arah. Penurunan nilai konduktivitas air berkorelasi dengan peningkatan efisiensi turbin. Kadar ion dan unsur pengotor yang sedikit dalam air pendingin berkorelasi dengan perpindahan panas yang baik, sehingga perpindahan panas dalam proses kondensasi di dalam kondensor dapat berjalan optimal. Tekanan kondensor yang semakin vakum dapat membantu kerja turbin dalam memaksimalkan energi panas uap yang masuk sehingga konsumsi uap semakin sedikit. Konsumsi uap yang sedikit dalam pembangkitan daya listrik yang sama merupakan peningkatan efisiensi turbin. Hasil ini dibuktikan dari data sampel dengan nilai konduktivitas tertinggi sebesar $1479.45 \mu \mathrm{S} / \mathrm{cm}$ dan efisiensi turbin uap yang rendah sebesar $61.2 \%$. Visualisasi korelasi ini dapat dibuktikan pada gambar scatter plot 
berikut.

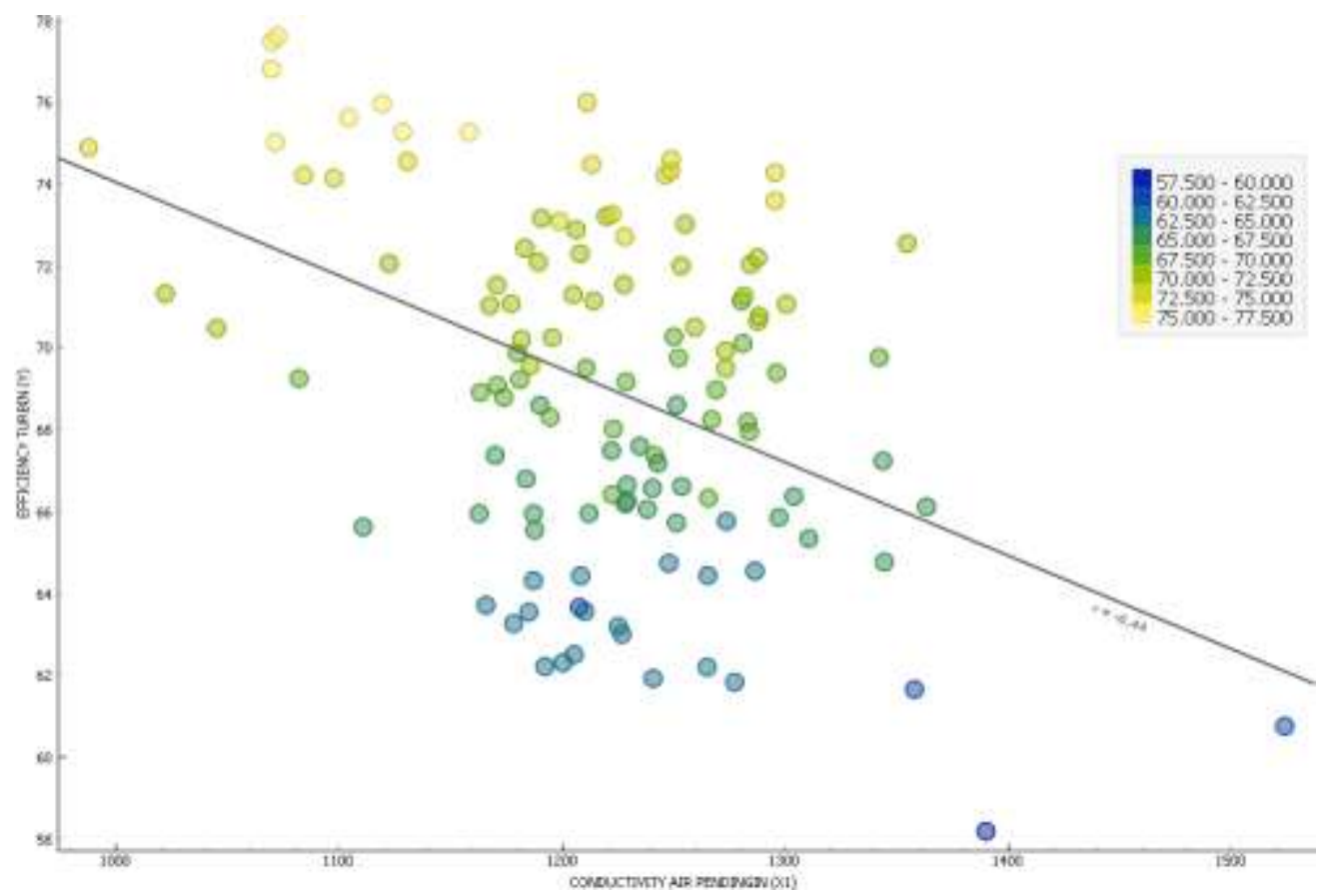

Gambar 8. Scatter plot konduktivitas air vs efisiensi turbin

Hasil uji korelasi antara konduktivitas air pendingin dengan efisiensi turbin dapat dikuatkan dengan diagram distribusi konduktivitas air terhadap efisiensi seperti berikut.

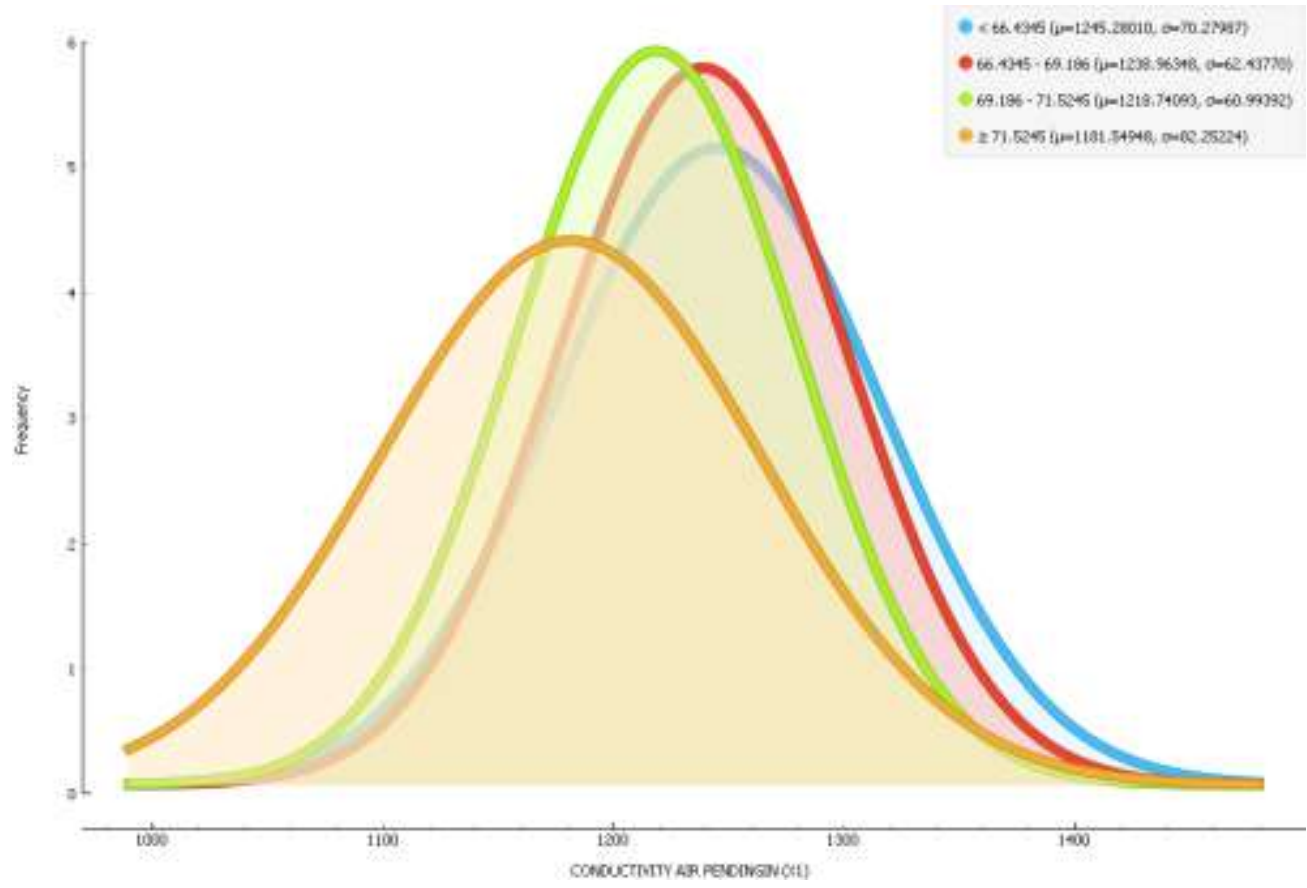

Gambar 9. Distributions konduktivitas air vs efisiensi turbin

Kumpulan nilai efisiensi yang lebih besar dari $71.5 \%$ berada dalam nilai rata-rata konduktivitas air pendingin dengan nilai $1181 \mu \mathrm{S} / \mathrm{cm}$. Sedangkan kumpulan nilai efisiensi yang lebih kecil dari $66.4 \%$ berada dalam nilai rata-rata konduktivitas air pendingin dengan nilai $1248 \mu \mathrm{S} / \mathrm{cm}$. Sehingga dapat disimpulkan bahwa korelasi konduktivitas air pendingin dengan efisiensi memiiki korelasi yang cukup kuat dan berlawan arah. Implikasi yang perlu 
diperhatikan dari hasil penelitian ini adalah nilai konduktivitas air pendingin harus dikontrol untuk menjaga tingkat keefisienan turbin, dapat dilakukan dengan menginjeksikan cairan kimia untuk mengurangi zat impurities pada air pendingin.

\section{SIMPULAN}

Setelah dilakukan pengumpulan data dari lapangan PLTP Karaha 1x30 MW dengan kondisi pembangkitan rata-rata $30 \%$ dari kapasitas yang terpasang dan dilakukan perhitungan serta analisa uji korelasi nilai konduktivitas air pendingin terhadap efisiensi turbin uap PLTP Karaha, maka dapat disimpulkan bahwa :

1. Diantara laju aliran masa uap, tekanan kondensor, temperatur pendingin dan konduktivitas air, nilai koefisien pearson correlation terhadap efisiensi paling besar dimiliki konduktivitas air pendingin. Konduktivitas air dengan efisiensi turbin memiliki korelasi yang cukup kuat dan berlawan arah dengan nilai koefisien pearson correlation sebesar -0.436 . Konduktivitas air pendingin yang rendah berkorelasi dengan efisiensi yang tinggi.

2. Perubahan konduktivitas memiliki korelasi yang kuat dengan temperatur air pendingin dan kevakuman kondensor, yang berpengaruh terhadap laju aliran uap untuk menghasilkan energi listrik. Terbukti dengan nilai koefisien pearson correlation efisiensi terhadap laju aliran uap sebesar +0.384. Semakin tinggi konsumsi uap yang dipakai maka efisiensi turbin uap semakin rendah.

3. Konduktivitas air pendingin dengan nilai rata-rata $1181 \mu \mathrm{S} / \mathrm{cm}$ memiliki efisiensi turbin diatas $71.5 \%$, sedangkan konduktivitas air pendingin dengan nilai rata-rata $1248 \mu \mathrm{S} / \mathrm{cm}$ memiliki efisiensi turbin dibawah $66.4 \%$.

\section{UCAPAN TERIMA KASIH}

Penulis mengucapkan terima kasih kepada Ir. Aryantono Mortowidjojo,Ph.D dan Ir.PriyonoAtmadi,M.Sc selaku dosen pembimbing yang telah meluangkan waktu, pikiran dan energinya untuk membimbing, memberi saran hingga terselesaikannnya artikel ilmiah ini. Serta seluruh pekerja PT. PGE Area Karaha yang telah banyak membantu penulis dalam pengumpulan data serta diskusi yang dibutuhkan oleh penulis.

\section{DAFTAR PUSTAKA}

[1] N. M. Saptadji, "Karakterisasi Reservoir Panas Bumi," Bandung Inst. Teknol. Bandung, vol. Juli, pp. 6-17, 2009.

[2] D. Erlina Lestari, "Kajian Awal Perilaku Silika Dalam Air Pendingin Primer Reaktro RSG-Gas," Kaji. Awal Perilaku Silika Dalam Air Pendingin Prim. Reakt. Rsg -Gas, vol. 53, no. 9, pp. 1689-1699, 2015.

[3] S. B. U. Djunaidi, "Pemakaian Inhibitor Untuk Pengendalian Korosi Pada Sistem Pendingin Sekunder RSG-GAS," in Buletin Pengelolaan Reaktor Nuklir. Vol. 4 No. 2, Oktober 2007 : 51-58, vol. 4, no. 2, 2007, pp. 51-58.

[4] A. Sukarno, Bono, and B. Prasetyo, "Analisa Perubahan Tekanan Vakum Kondensor Terhadap Kinerja Kondensor di PLTU Tanjung Jati B Unit 1," vol. 10, no. 2, pp. 65-71, 2014.

[5] M. J. Moran and H. N. Shapiro., Fundamentals of Engineering Thermodynamics. 2006.

[6] N. J. Gogtay and U. M. Thatte, "Principles of correlation analysis," J. Assoc. Physicians India, vol. 65, no. MARCH, pp. 78-81, 2017. 